\title{
RELATIONSHIP AND GENETIC DIVERSITY OF MISTLETOE (VISCUM ALBUM L.) SUBSPECIES
}

\author{
LEON MEJNARTOWICZ \\ Polish Academy of Sciences, Institute of Dendrology \\ Parkowa 5, 62-035 Kórnik, Poland \\ e-mail: idkornik@man.poznan.pl
}

(Received: August 8, 2005. Accepted: January 12, 2006)

\begin{abstract}
With the help of 21 putative isoenzyme loci, the genetic diversity and variations of Viscum album ssp. album L. from 42 species, subspecies, varieties and hybrids of broadleaf trees, Viscum album ssp. austriacum (Wiesb.) Vollmann, from 4 populations of Scots pine (Pinus sylvestris L.) and Viscum album ssp. abietis (Wiesb.) Abromeit, from 8 populations of European silver fir (Abies alba Mill.) were analyzed. On the dendrogram, the three investigated subspecies form three clusters, each clearly separated from the other, so we suggest a revision of the systematic nomenclature proposed to take into consideration a return to an earlier system of dividing the European mistletoe into three species: Viscum album L., Viscum abietis Beck, and Viscum laxum Boiss. et Reut. From among the 21 tested loci only one locus, SOD-A, was monomorphic. The average number of actual alleles $\left(N_{a}\right)$ and effective alleles $\left(N_{e}\right)$ was 2.23 and 1.61 respectively. The observed heterozygosity $\left(H_{o}\right)$ varied from 0.199 in $V$. album ssp. abietis to 0.345 in the V.a. ssp. album populations. Average $F_{S T}=0.277$ indicates that about $28 \%$ of genetic differentiation is due to an interpopulation diversity of Viscum album populations. There is a small gene flux between Viscum album populations with only one immigrant successfully entering a population per two generations $\left(N_{m}=0,653\right)$.
\end{abstract}

KEY WORDS: Viscum album, V. abietis, V. austriacum, isozymes, heterozygosity, genetic diversity, genetic distance, gene flow.

\section{INTRODUCTION}

There is a vast literature, about 12000 papers, on mistletoe, dealing mainly with two areas: 1) medical and pharmaceutical application of mistletoe in drug production, and 2) list of host species. The interest in mistletoe among pharmacologists, especially in recent years, has stemmed from the discovery of a large number of substances obtained from tissues of this semi-parasite: alkaloids, flavonoids, phenylopropanes, polysaccharides, lectines, and viscotoxins with cytostatic, immunostimulative, sedative, anticancerous (inducing apoptosis of cancerous cells), supporting AIDS treatment and other properties (Fischer et al. 1996; Karkabounas et al. 2000; Schröder 1982, Smith 1989).

Mistletoe is deleterious to its host, impeding the tree's growth, deforming its crown, increasing the risk of bacterial or fungous diseases, and predisposing trees to beetle attacks (Noetzl et al. 2003; Tsopelas et al. 2004; Zenkteler 1996). The semiparasitic mistletoe attacks many species of deciduous trees and some conifers, mainly the European silver fir (Abies alba Mill.) and Scots pine (Pinus sylvestris L.).
In Poland, and in many other European countries, the occurrence of mistletoe has increased drastically over the last two decades, occupying new areas and new species in forests, parks and fruit-tree collections (Barney et al. 1998; Böhling et al. 2002; Stypiński 1997; Vallauri 1998; Zieliński 1997). There is, however, very little literature dealing with mistletoe genetic variations. Only recently some papers have appeared on this issue, based on DNA analysis (Nagl and Stein 1989; Piotrowski et al. 2003; Zuber and Widmer 2000).

In Polish literature, Szafer et al. $(1924,1953)$ divided genus Viscum, from Central Europe, into three taxonomic units - each in the rank of species: Viscum album L., Viscum abietis (Beck) and Viscum laxum (Boiss.) Similar taxonomy can be found also in newer literature (Bergmeier 1994; Boratyński and Boratyńska 1976; Ehrendorfer 1967; Lindacher 1995). The present study applied, after "Flora Europaea" (Ball 1964) and "Vascular plants of Poland" (Mirek et al. 1995) the taxonomic division of Viscum album L. into three subspecies: (1) V. album ssp. album (= Viscum album L.) - most frequently occurring in Poland, the common mistletoe living on deciduous trees; (2) $\mathrm{Vi}$ scum album ssp. abietis (Wiesb.) Abromeit (= Viscum 
abietis Beck.) growing on the European silver fir tree and (3) Viscum album ssp. austriacum (Wiesb.) Vollmann (= Viscum laxum Boiss. et Reut.) the mistletoe living on the Scots pine tree. For the systematics literature review, see Zuber (2004). Because the mistletoe possesses a sex-complex heterozygosity (Mechelke 1976), in the cases when determining the parasite gender was possible, the material from male and female individuals was analyzed separately.

The questions raised were:

1. Are there any differences in types and in frequency of occurrence of different alleles in presumed isozymes loci of Viscum subspecies growing on different hosts of deciduous trees and coniferous Scots pine and silver-fir?

2. What is the genetic variation and diversity in mistletoe populations?

3. What is the level of inbreeding in populations and of the gene flux between mistletoe populations?

4. Are there any differences in the isozymes allele frequencies between male and female mistletoe shrubs?

\section{MATERIALS AND METHODS}

\section{Plant material}

With the help of 21 isozymes, putative loci mistletoe growing on 45 host species, subspecies, varieties, and tree hybrids were studied. We tried to find significant differences in the frequency of occurrence of specific alleles between V. album ssp. austriacum, V.a. ssp. abietis, and V.a. ssp. album. For interpopulation genetic variance analyses, a total of 307 mistletoe shrubs were sampled from 19 populations. In this paper, as 'population' we understand the mistletoe plant sample from one host taxon from one investigated area. The sites of our plant material collections are presented on the map (Fig. 1). Nine populations parasitizing on broadleaf trees were collected in Kórnik Arboretum in western Poland. From this region originated also four populations colleted from Scots pine (Pinus sylvestris L.) in Forest Inspectorates Babki, District Kórnik (No. 10),

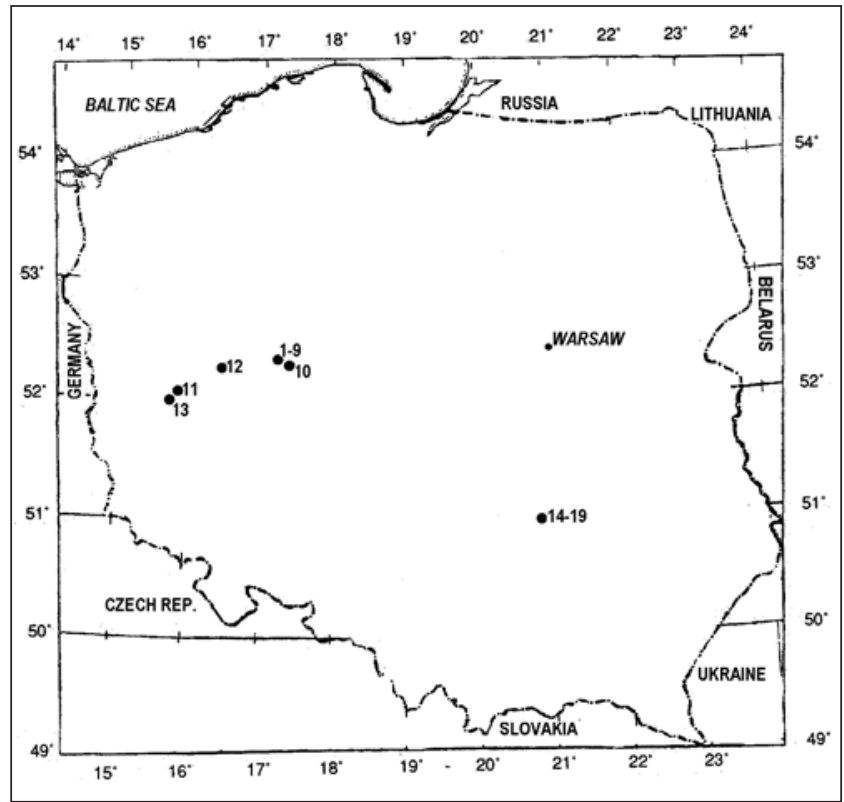

Fig. 1. A map showing locations of the studied sites with mistletoe parasitising broadleaves trees (1-9), Scots pine (10-13) and European silver fir (14-19) host populations.

Rakoniewice (No. 12) and Sława Śląska (District Kolsko, No. 11 and 13). Six populations from European silver fir (Abies alba Mill.) were collected in southern Poland in Forest Inspectorate Chmielnik, Districts Drugnia (populations No. 14-17) and Papiernia (No. 18 and 19). The number of collected individuals is not the same for each population because different numbers of parasite plants were found on different host tree species, subspecies, varieties or hybrids. The most abundant sample originated from Tilia cordata $\mathrm{L}$. To diminish environmental effects on isozyme variation in mistletoe tissue, we collected for the analysis 31 samples growing on the ramets of one clone Malus purpurea Rehd. The list of all investigated mistletoe samples according to the host species is presented in Table 1 .

\section{Electrophoretic analysis}

Young mistletoe leaves, with dimension not greater than 1.5-2 $\mathrm{mm}$, were collected at the beginning of vegetative se-

TABLE 1. Broad leaves hosts species, subspecies, varieties or hybrids investigated Viscum album ssp. album, and Abies alba and Pinus sylvestris hosts trees for V. album ssp. abietis and V. album ssp. austriacum respectively.

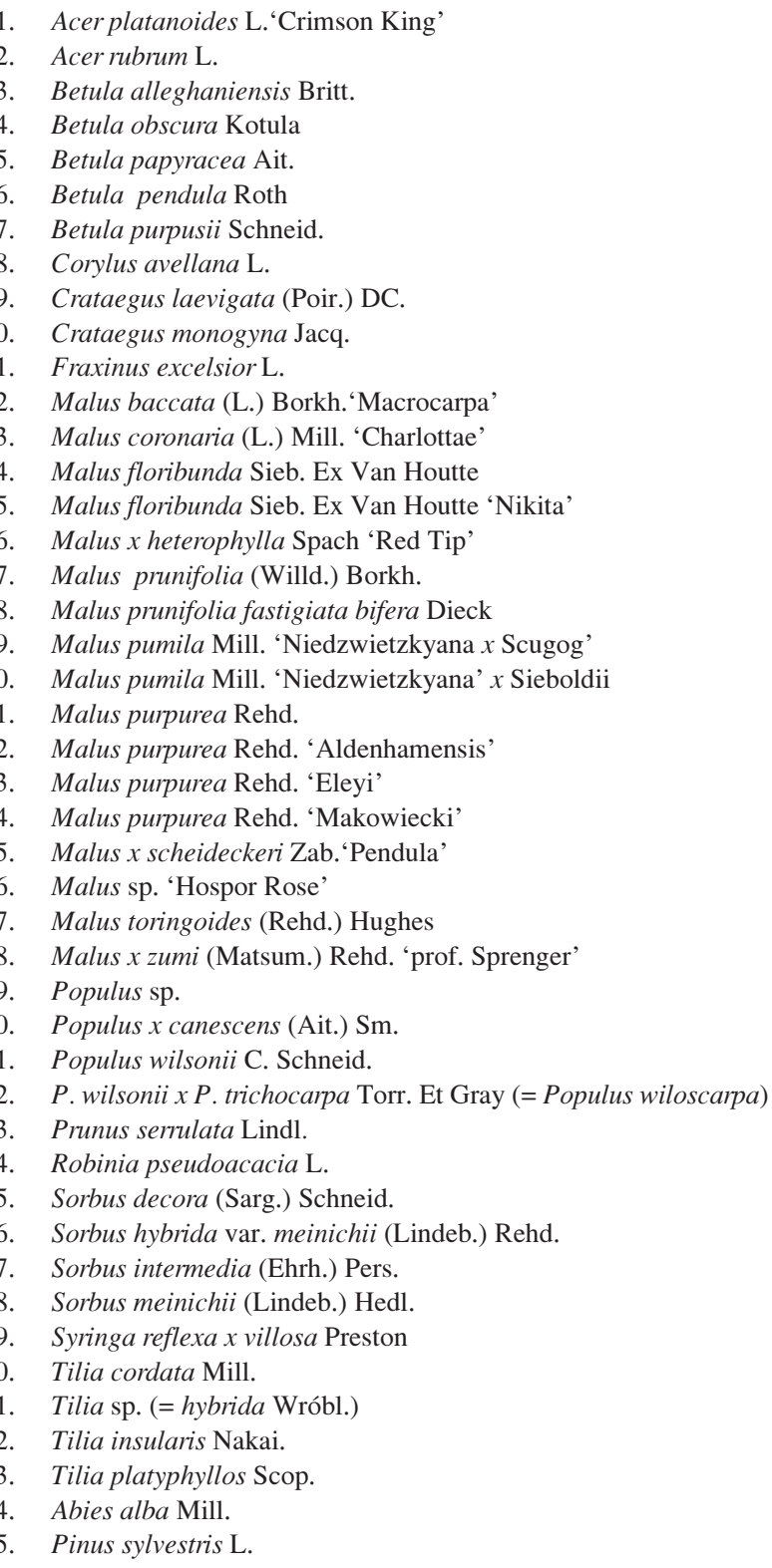


ason in the second half of February and March. The samples, about $2.5 \mathrm{~cm}$ in stem length were frozen in liquid nitrogen and stored at $-80^{\circ} \mathrm{C}$ for electrophoresis. In a chilled mortar and pestle, the leaves were homogenized with a power homogenizer in $150 \mu \mathrm{l}$ of $0.1 \mathrm{M}$ TRIS-HCl, $\mathrm{pH} 7.2$, buffer containing $10 \mathrm{mg}$ polyclar AT (unsoluble polyvinylpyrrolidone), $30 \mathrm{mg}$ PVP, $15 \mu \mathrm{l} \beta$-mercaptoethanol and 5 $\mu 1$ non-ionic surfactant Triton $\mathrm{X}-100$ and $50 \mathrm{mg}$ quartz sand. For electrophoresis the supernatant was applied on wicks of Whatman $3 \mathrm{MM}$ filter paper. Electrophoresis was carried out on $11.5 \%$ starch gels at $+4^{\circ} \mathrm{C}$. Separation systems used in this process are presented in Table 2, and investigated enzymes in Table 3. Stability of the isozymes activity investigated as genetic markers in the mistletoe's leaves enable to distinguish hemi-parasite taxa differing in their host specificity.

The review of literature on genetics of plant isozymes describes "...stability of locus number for specific enzyme systems and the consistent subcellular compartmentation of the isozymes" (Weeden and Wendel 1989, 1989a). As neither the controlled crosses nor the offspring of single mistletoe shrubs were available, we carried out the genetic analysis comparing the putative mistletoe leaf isozymes loci to the well-known isoenzyme zymograms of megagametophytes of previously studied host species of Abies alba and Pinus sylvestris, used as standard references (Berg- mann and Mejnartowicz 2001, 2002; Mejnartowicz 1996, 2004; Mejnartowicz and Bergmann 2003). In the present work, allele numbering corresponds to isoenzyme $R f$ : the fastest allozyme migrating toward anode was marked 1, next 2 , and so on.

\section{RESULTS AND DISCUSSION}

\section{Genetic diversity and variation}

Electrophoretic mobility of the Viscum album isozymes in prospective gene loci is presented schematically in Figure 2 and the frequency of alleles in the 19 investigated populations - in Table 4. For estimation of genetic diversity and variation in populations, the following numbers were calculated: mean number of alleles per locus $\left(N_{a}\right)$, effective number of alleles at locus $\left(N_{e}\right)$, number of rare alleles $(\mathrm{No}$ $-R a)$, proportion of polymorphic loci $(\% P O L)$, and Shannon's index of genetic diversity $(I)$. Calculated was also the observed $\left(H_{o}\right)$ and expected $\left(H_{e}\right)$ heterozygosity (Nei 1978). Gene frequency differences among subdivided populations were calculated as Wright's (1965) fixation indices: $F_{I S}, F_{I T}$, and $F_{S T}$. More information on fixation indices $F$ and estimated gene flow $N_{m}$ is given by Nei (1987) and Whitlock and McCauley (1999). The statistical analysis of allele frequencies and the cluster analysis were performed

TABLE 2. Separation systems for starch gel electrophoresis of isozymes in Viscum album.

\begin{tabular}{|c|c|c|c|c|c|}
\hline \multirow{2}{*}{ Gel components } & \multicolumn{2}{|c|}{ Running condition } & \multirow{2}{*}{$\begin{array}{c}I \text { const. } \\
{[\mathrm{mA}]}\end{array}$} & \multirow{2}{*}{$\begin{array}{c}\text { Time } \\
{[\mathrm{h}]}\end{array}$} & \multirow{2}{*}{$\begin{array}{l}\text { Temp. } \\
{\left[{ }^{\circ} \mathrm{C}\right]}\end{array}$} \\
\hline & Electrode buffer & Gel buffer & & & \\
\hline $\begin{array}{l}\text { 1) } \text { Tris }^{1} \text { - citrate system } \\
11,5 \% \text { starch } \\
+4 \% \text { sucrose }\end{array}$ & $\begin{array}{c}\text { Tris-citrate } \mathrm{pH} 7.5 \\
\mathrm{pH} 7.5\end{array}$ & E-buffer add. $75 \% \mathrm{H}_{2} \mathrm{O}$ & 60 & 5 & 3 \\
\hline $\begin{array}{l}\text { 2) Ashton-system } \\
11 \% \text { starch } \\
+2 \% \text { sucrose }\end{array}$ & $\begin{array}{c}0.03 \mathrm{M} \mathrm{LiOH}^{-} \mathrm{M} \mathrm{H}_{3} \mathrm{BO}_{3} \\
\mathrm{pH} 8.1\end{array}$ & $\begin{array}{c}0.05 \text { M Trees-citrate } \mathrm{pH} 8.1 \\
10 \% \text { Electrode buffer }\end{array}$ & 60 & 4.5 & 3 \\
\hline
\end{tabular}

${ }^{1}$ [Tris-hydroxylmethyl-aminomethane], $\mathrm{C}_{4} \mathrm{H}_{11} \mathrm{NO}_{3}$

TABLE 3. Enzyme systems assayed in the tissue of mistletoe leaves.

\begin{tabular}{|c|c|c|c|c|}
\hline Enzyme system E.C. number & Investigated loci & Allele number & No. of frequent allele & Separat. systems \\
\hline Alcohol dehydrogenase E.C. 1.1.1.1 & ADH-1 & 3 & 1 & 1 \\
\hline$\alpha$-Esterase E.C. 3.1.1.1 & EST-2 & 5 & 3 & 2 \\
\hline Fluorescence esterase E.C. 3.1.1.2 & FLE-1 & 5 & 2 & 2 \\
\hline Glutamate dehydrogenase E.C. 1.4.1.2 & GDH-1 & 3 & 2 & 2 \\
\hline Glutamate-oxaloacetate-transamin. E.C. 2.6.1.1 & GOT-1 & 6 & 3 & 2 \\
\hline \multirow[t]{2}{*}{ Isocitrate dehydrogenase E.C. 1.1.1.42 } & IDH-1 & 4 & $2 ; 3$ & 1 \\
\hline & IDH-2 & 3 & 3 & 1 \\
\hline Leucine aminopeptidase E.C. 3.4.11.1 & LAP-1 & 4 & $2 ; 3$ & 2 \\
\hline \multirow[t]{4}{*}{ Malate dehydrogenase E.C. 1.1.1.37 } & MDH-1 & 5 & $2 ; 3$ & 1 \\
\hline & MDH-2 & 6 & $1 ; 2 ; 3$ & 1 \\
\hline & MDH-3 & 2 & 2 & 1 \\
\hline & MDH-4 & 5 & 3 & 1 \\
\hline Menadione reductase E.C. 1.6.4.3 & MEN-1 & 2 & 1 & 1 \\
\hline \multirow[t]{2}{*}{ Phosphoglucomutase E.C. 5.4.2.2 } & PGM-1 & 3 & 1 & 2 \\
\hline & PGM-2 & 2 & 2 & 2 \\
\hline Phosphoglucose isomerase E.C. 5.3.1.9 & PGI-1 & 4 & 3 & 2 \\
\hline 6-Phosphogluconic dehydrogenase E.C. 1.1.1.44 & 6PGD-1 & 3 & 3 & 1 \\
\hline Shikimate dehydrogenase E.C. 1.1.1.25 & ShDH-1 & 2 & 2 & 1 \\
\hline \multirow[t]{2}{*}{ Superoxide dismutase E.C.1.15.1.1 } & SOD-1 & 1 & 1 & 2 \\
\hline & SOD-2 & 4 & 3 & 2 \\
\hline Sorbitol dehydrogenase E.C.1.1.1.14 & $\mathrm{SrDH}$ & 3 & 2 & 2 \\
\hline
\end{tabular}




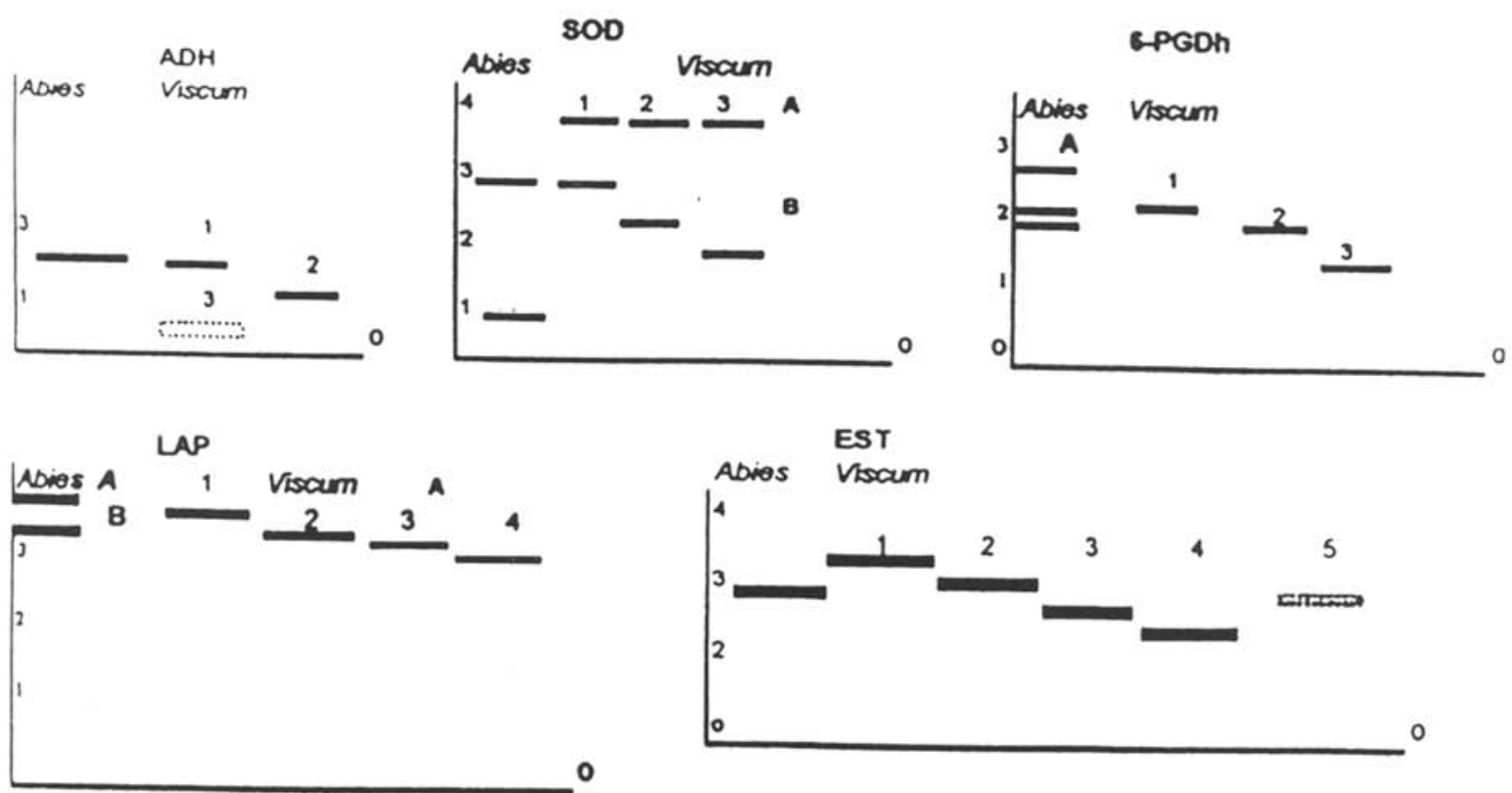

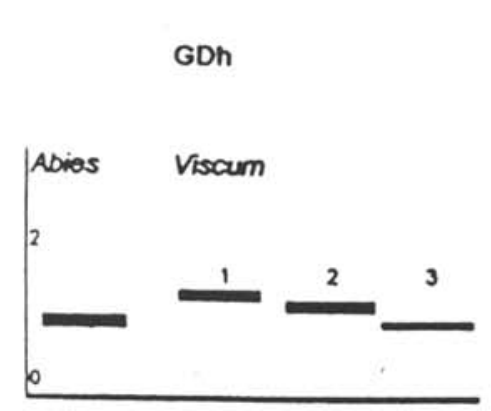

MDh

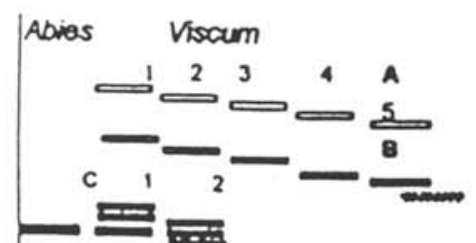

ㅍ.
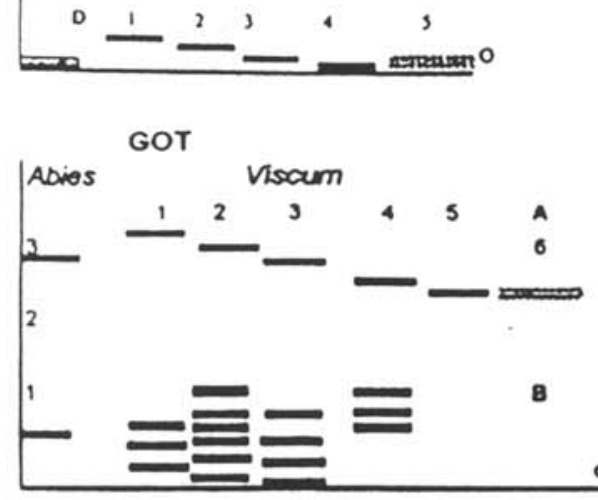

\section{FE}
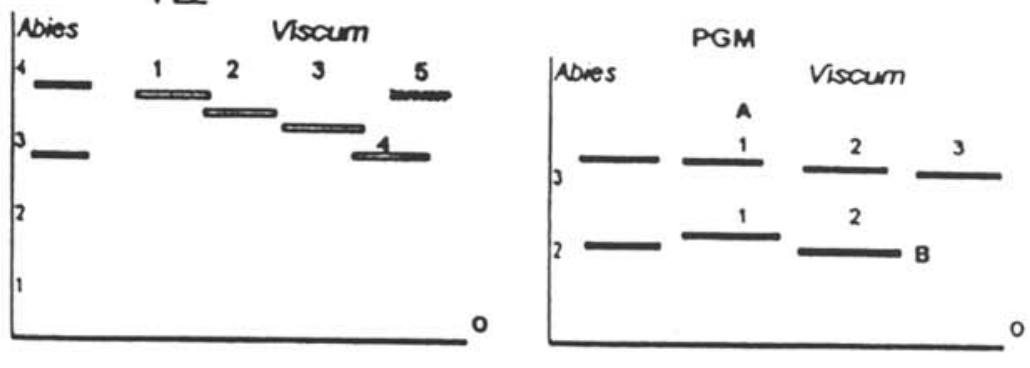

$P$ PI

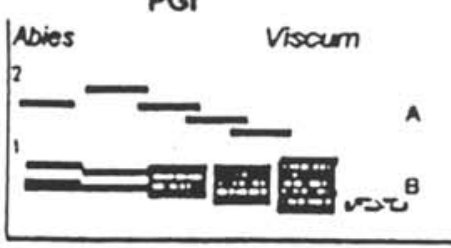

$\circ$

Idh
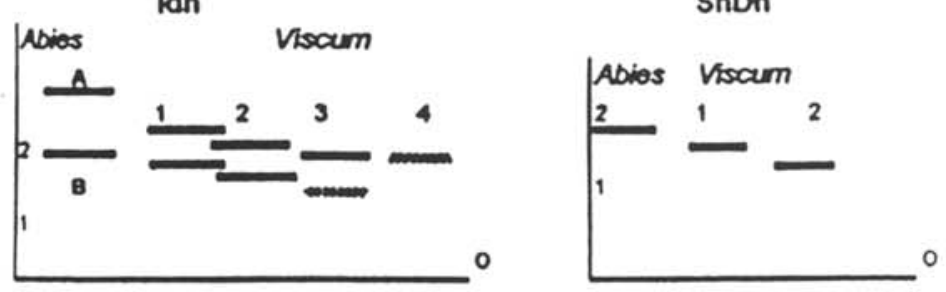

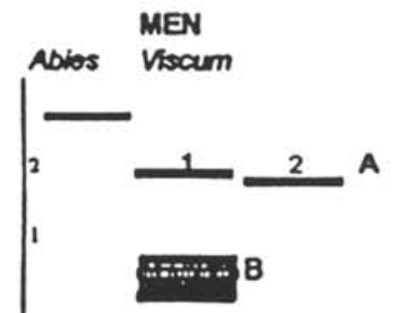

Fig. 2. Schematic illustrations banding pattern of isozymes from leaves tissue of mistletoe (Viscum album s.1.) and reference isozymes from Abies alba megagometophytes. The diagram shows the position of all the bands observed and the genetic interpretation of the alleles of putative loci. Doted box denotes recessive (null) allele. Allele numbering corresponds to enzyme $R_{f}$. 


\begin{tabular}{|c|c|c|c|c|c|c|c|c|c|}
\hline $\mid \frac{8}{2}$ & $=-00$ & 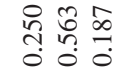 & 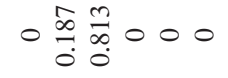 & 0 ०. & 䚄 & $0-0$ & $00-00$ & 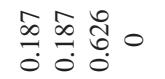 & 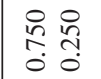 \\
\hline 尊 & $\simeq-\infty$ & 总员 & 00 舫总。 & 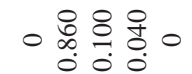 & 赵赵赵。 & $0-0$ & $00-00$ & 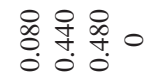 & $\begin{array}{ll}0 \\
\text { o. } \\
0 \\
0\end{array}$ \\
\hline 尊 & $=-00$ & 总量 & $00-000$ & 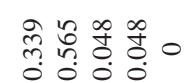 & 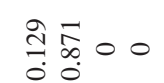 & $0-0$ & o o & 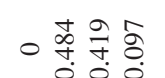 & -0 \\
\hline 尊 & $\because-\infty$ & 总员 & $00-000$ & 势会 000 & & $0-0$ & $00-00$ & 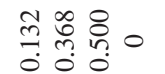 & -0 \\
\hline 竞 & $=-00$ & $\begin{array}{ll}n \\
m \\
m \\
0 \\
0\end{array}$ & $00-000$ & 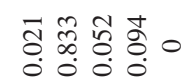 & 궁영 & $0-0$ & $00-00$ & 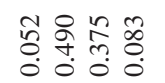 & $\mid \begin{array}{ll}0 & 0 \\
0 & 0 \\
0 & 0\end{array}$ \\
\hline 卷 & $\pm-\infty$ & 总品 & 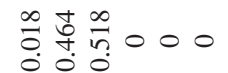 & 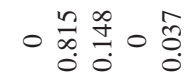 & 0. & $0-0$ & $00-00$ & o $8 \begin{array}{c}8 \\
0 \\
0\end{array}$ & 0 \\
\hline 惫 & $=-00$ & ○早宫 & 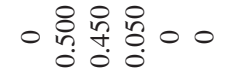 & ○ & ○苔员造 & 命 & $00-00$ & 象员。 & - 0 \\
\hline 鄫 & 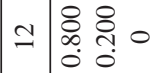 & 0 o & $0-0$ & $0-000$ & & $0-0$ & ○ $0 \begin{array}{c}8 \\
0 \\
0\end{array} 0$ ○ & 융융. & - \\
\hline 厗 & $=-00$ & 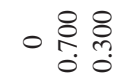 & 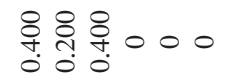 & 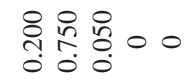 & $\begin{array}{l}0 \\
\mathrm{~m}_{0} \\
0\end{array}$ & $0-0$ & 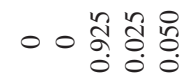 & 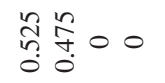 & \\
\hline 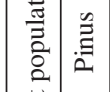 & $=-00$ & 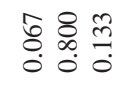 & 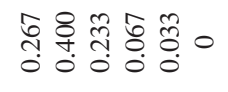 & 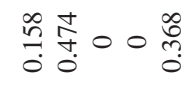 & 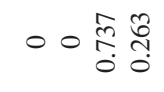 & 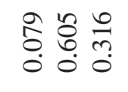 & 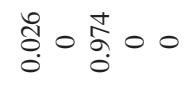 & $\begin{array}{ll}0 \\
0 \\
0 \\
0\end{array} 0.0$ & $\mid$ \\
\hline 蒫 & $0-00$ & 0 व్ర్రి & 00 & 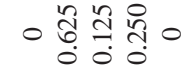 & o & $0-0$ & 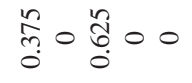 & 寗。 & \\
\hline 完 & $\infty-\infty$ & 总品 & $0 \stackrel{n}{m}$ & בุ & & â. & 总。品00 & 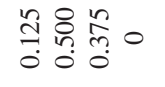 & in \\
\hline 这 & $r-\infty$ & 0 & $0 \stackrel{\substack{0 \\
0}}{0}$ & 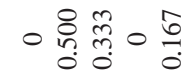 & $0 \stackrel{0}{0} 0$ & $\begin{array}{l}0 \\
0 \\
0 \\
0\end{array}$ & $00-00$ & 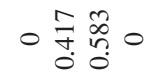 & 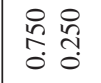 \\
\hline 竞 & $0-00$ & 恿总 & 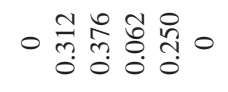 & 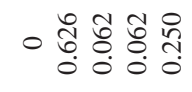 & 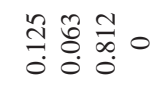 & $0-0$ & 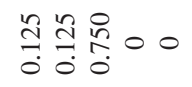 & 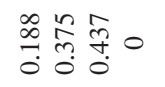 & 30 \\
\hline$\frac{n}{\frac{n}{2}}$ & in $\frac{n}{a} 00$ & o & 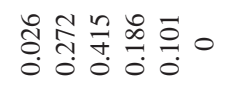 & 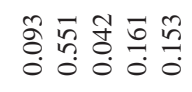 & $\begin{array}{l}0 \\
g_{0} \\
0 \\
0\end{array}$ & 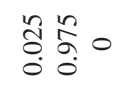 & 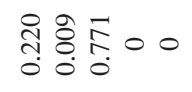 & 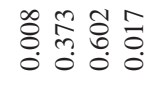 & $\vec{s}$. \\
\hline 㻤 & $+-\infty$ & 总尊 & $\begin{array}{ll}0 \\
0 \\
0\end{array}$ & 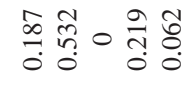 & & 高管。 & 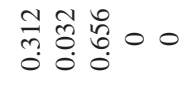 & $\begin{array}{ll}\tilde{b} \\
0 \\
0\end{array}$ & \\
\hline$\frac{9}{3}$ & $m-\infty$ & $\begin{array}{l}\infty \\
0.0 \\
0.0 \\
0 \\
0\end{array}$ & 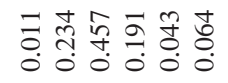 & 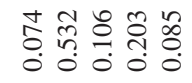 & 0 & 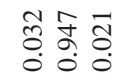 & 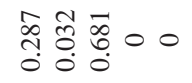 & 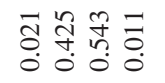 & $\mid \begin{array}{ll}n & 0 \\
a & 0 \\
0 & 0 \\
0 & 0\end{array}$ \\
\hline 㝘 & $\therefore-\infty$ & o & 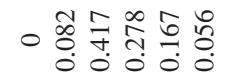 & 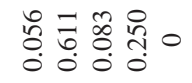 & ○ & 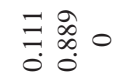 & 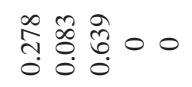 & 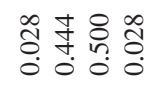 & $\begin{array}{ll}\infty & 0 \\
0 & 0 \\
0 & 0 \\
0 & 0\end{array}$ \\
\hline 言 & $-1-00$ & o & 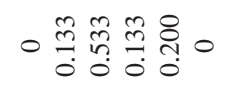 & 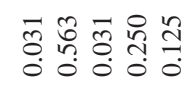 & 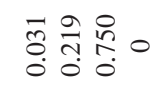 & 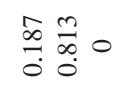 & 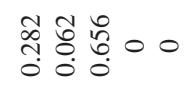 & ma & $\begin{array}{lll}\infty & 0 \\
\infty & 0 \\
0 & 0 & 0 \\
0 & 0 & 0\end{array}$ \\
\hline 7 & - am & $-n$ & $-a c$ & $+i$ & & $-a m$ & $-n m+n$ & $m+$ & \\
\hline$\stackrel{9}{9}$ & 竞 & ग्ञ & $\overline{0}$ & 嵵 & 呞 & 苂 & 5 & 3 & $1 \Sigma$ \\
\hline
\end{tabular}




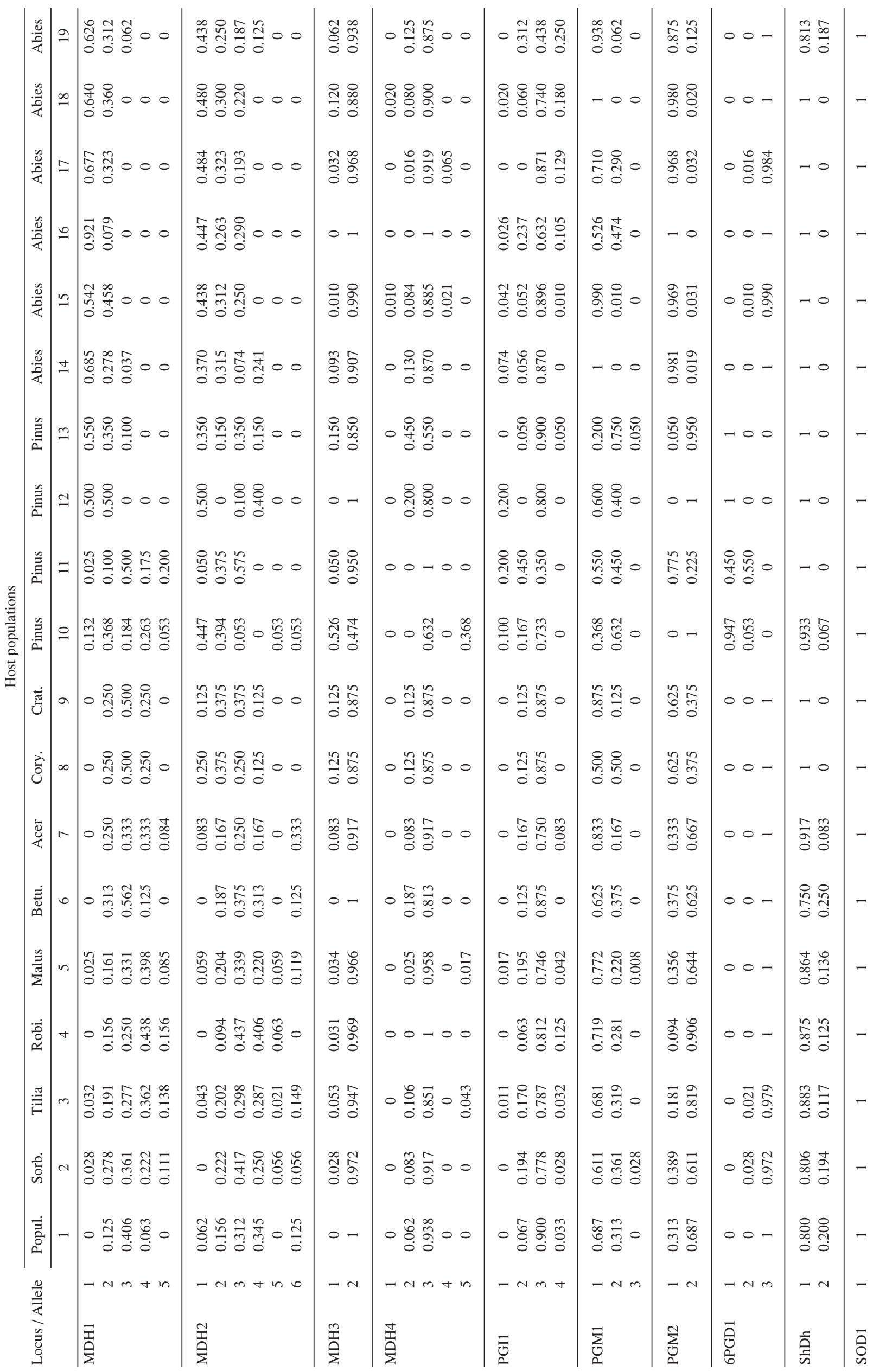




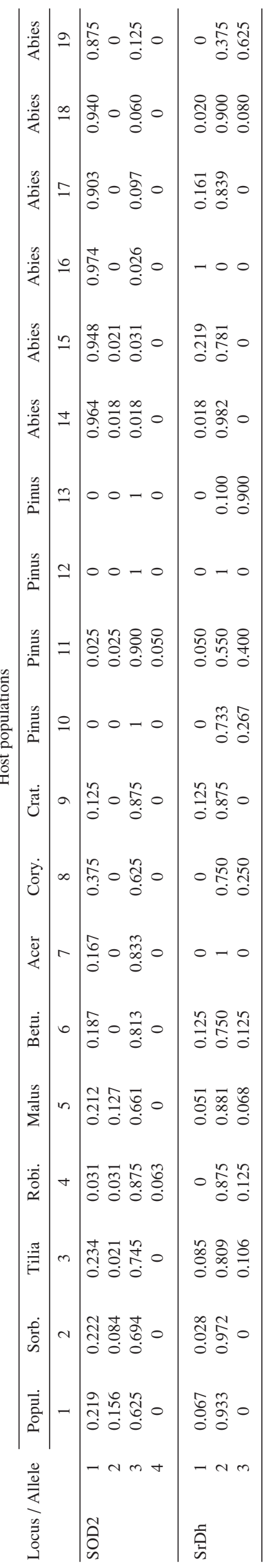

with the Popgene-32 program (Yeh and Yang 1999). Results are presented in Table 5.

Only one of the 21 tested loci, SOD-A (=SOD-1), was monomorphic, irrespective of the host species. All mistletoes had SOD-A1A1 genotype. The second locus, SOD-B (=SOD-2), had four alleles, varying in frequency of occurrence in the particular mistletoe subspecies. In the populations of V.a. ssp. abietis, B1 allele was very frequent, $\mathrm{p}>0.875$, while in the populations of V.a. ssp. album and ssp. austriacum B3 allele was very frequent, $\mathrm{p}>0.625$, (Table 4). Two other loci, 6PGD and ADH, were semimonomorphic in character, however, in one population of V.a. ssp. austriacum $20 \%$ of the individuals had ADH-2 allele. In one population of V.a. ssp. album, parasitizing on Malus sp. private allele ADH-3 was found in frequency $\mathrm{p}=0.085$ (Table 4). Populations of $V$. album ssp. abietis appeared the least variable genetically. The number of observed and effective alleles $\left(N_{a}=1.976\right.$ and $\left.N_{e}=1.419\right)$ in these populations is significantly lower than that in the populations of $V$. album ssp. album, where $N_{a}=2.476$ and $N_{e}=1.734$, and much closer to the mistletoe population parasitizing on the pine with $N_{a}=2.06$ and $N_{e}=1.6$ (Table 5). Genetic diversity of mistletoe population, described as a mean number of observed and effective alleles is surprisingly similar to the genetic diversity described in the European silver fir, with $N_{a}=2.31$ and $N_{e}=1.54$, and Norway spruce, with $N_{a}$ $=2.17$ and $N_{e}=1.26$ (Lewandowski and Burczyk 2002; Mejnartowicz 2004).

Genetic diversity described with Shanon's $I$ index is much greater in $V$. album ssp. album populations $(I=$ $0.557)$, than in populations of $V$. album ssp. austriacum $(I=0.454)$, or $V$. album ssp. abietis $(I=0.345)$ (Table 4).

\section{Number of rare alleles (NoRa)}

In all investigated mistletoe subspecies, the populations differed significantly in the number of rare alleles $(\mathrm{NoRa})$ (Table 5). The greatest number of rare alleles, $N o R a=16$, was found in one population parasitizing on Tilia cordata, and, NoRa $=14$, on Abies alba and Malus purpurea. In the latter population, parasitizing on one clone of Malus purpurea, $38 \%$ reduction in heterozygosity was found, as a result of inbreeding (Table 5). Since in this case Malus purpurea is a clone, the influence of the host on the number of mutations described in particular mistletoe individuals must be excluded. It is possible that the accumulation of rare mutations in some populations of mistletoe results from inbreeding, migration or frequency depending selection and spatial environmental heterogeneity combined with hosts species diversity. New alleles originating in mutation can be lost or fixed in the population. In small populations rare alleles may be fixed through a genetic drift. In populations of smaller effective size the probability is greater of fixing deleterious alleles but, on the other hand, the population structure causes increase in homozygosity of alleles, which increases the probability of fixing beneficial and decreasing deleterious alleles (Whitlock 2003). Since the hosts are long lived trees, constituting stable populations where not all individuals are attacked, the mistletoe populations are smaller and younger than their hosts, so we could expect in the semi-parasite stronger population differentiation and more genetic drift (Whitlock and McCauley 1990; Giles and Goudet 1997). 
TABLE 5. Summary of Genetic Variation and Heterozygosity for Viscum album populations from different hosts.

\begin{tabular}{|c|c|c|c|c|c|c|c|c|}
\hline Host origin* & $N_{a}^{* *}$ & $N_{e}$ & $I$ & $H_{o}$ & $\boldsymbol{H}_{e}$ & $F_{I S}$ & $\% P o L$ & NoRa \\
\hline 1. Populus (No.: 27-30) & 2.524 & 1.740 & 0.580 & 0.299 & 0.347 & 0.082 & 80.95 & 5 \\
\hline 2. Sorbus (33-36) & 2.714 & 1.808 & 0.605 & 0.320 & 0.357 & 0.094 & 90.48 & 7 \\
\hline 3. Tilia cordata (38) & 3.048 & 1.818 & 0.621 & 0.262 & 0.346 & 0.271 & 90.48 & 16 \\
\hline 4. Robinia pseudoacacia (32) & 2.429 & 1.635 & 0.496 & 0.247 & 0.289 & 0.127 & 71.43 & 6 \\
\hline 5. Malus purpurea (19) & 3.000 & 1.799 & 0.602 & 0.232 & 0.336 & 0.381 & 90.48 & 14 \\
\hline 6. Betula pendula (5) & 2.286 & 1.734 & 0.560 & 0.315 & 0.357 & 0.031 & 76.19 & 0 \\
\hline 8. Corylus avellana (6) & 2.143 & 1.805 & 0.586 & 0.405 & 0.423 & -0.098 & 80.95 & 0 \\
\hline 9. Crataegus (7-8) & 1.952 & 1.547 & 0.448 & 0.345 & 0.316 & -0.150 & 71.43 & 0 \\
\hline Mean for V.a. ssp. album & 2.476 & 1.734 & 0.557 & 0.303 & 0.345 & 0.083 & 80.95 & 5.33 \\
\hline 10. Pinus sylvestris - Babki & 2.476 & 1.822 & 0.593 & 0.197 & 0.366 & 0.424 & 80.95 & 3 \\
\hline 11. P. sylvestris - Sławocin & 2.238 & 1.667 & 0.503 & 0.164 & 0.319 & 0.359 & 71.43 & 4 \\
\hline 12. P. sylvetris - Rakoniewice & 1.476 & 1.329 & 0.267 & 0.209 & 0.199 & -0.031 & 42.86 & 0 \\
\hline Mean for V.a. ssp. austriacum & 2.06 & 1.6 & 0.454 & 0.216 & 0.294 & 0.186 & 65.48 & 1.75 \\
\hline 14. Abies alba-Drugnia & 1.905 & 1.364 & 0.299 & 0.197 & 0.182 & -0.021 & 57.14 & 7 \\
\hline 15. Abies alba - Drugnia & 2.286 & 1.369 & 0.322 & 0.216 & 0.181 & -0.004 & 71.43 & 14 \\
\hline 16. Abies alba - Drugnia & 1.571 & 1.364 & 0.261 & 0.163 & 0.169 & 0.008 & 38.10 & 2 \\
\hline 17. Abies alba - Drugnia & 1.952 & 1.397 & 0.342 & 0.183 & 0.210 & 0.166 & 71.43 & 7 \\
\hline 18. Abies alba-Papiernia & 2.000 & 1.382 & 0.343 & 0.185 & 0.209 & 0.132 & 66.67 & 6 \\
\hline 19. Abies alba-Papiernia & 2.143 & 1.636 & 0.504 & 0.250 & 0.321 & 0.112 & 76.19 & 0 \\
\hline Mean for V.a. ssp. abietis & 1.976 & 1.419 & 0.345 & 0.199 & 0.212 & 0.066 & 63.49 & 6 \\
\hline Grand mean & 2.231 & 1.606 & 0.468 & 0.252 & 0.292 & 0.113 & 72.18 & 4.79 \\
\hline
\end{tabular}

* All broadleaves host tree sample are originated from Kórnik Arboretum (see Table 1). ** $N_{a}-$ mean number of observed allele; $N_{e}-$ mean number of effective allele; $\boldsymbol{I}$ - Shanon's index of genetic diversity; $\boldsymbol{H}_{\boldsymbol{o}}$ - observed heterozygosity; $\boldsymbol{F}_{\boldsymbol{I S}}-$ Wright' fixation index; $\% \boldsymbol{P o L}-$ percent of polymorphic loci; NoRa-No. of rare allele.

\section{Heterozygosity}

Viscum album is dioecious and thus an obligate outcrosser. The plants are entomophilous, pollinated by insects and by wind (Heinricher 1920; Wangerin 1937; Hatton 1963-1964). Pseudoberrys are mistletoe fruit (Kuijt 1969; Stop 1961). The "seeds" are sown by birds, usually quite close to their feeding ground. In this way, in some populations related individuals appear more frequently, especially in view of the fact that the "seeds" of Viscum album ssp. album are diembrional in 58\%. Berries of $V$. album ssp. austriacum have $16 \%$ of diembrional "seeds", and V.a. ssp. abietis $-11 \%$. However rarely, yet tri- and tetra-embrional "seeds" also occur (Wangerin 1937), and as a result we find shrubs of 2; 3 or even 4 mistletoe individuals deriving from one mother, producing poliembrional seeds; thus mistletoe shrubs growing on one host tree can be closely related.

There exist great differences in the level of NoRa and heterozygosity between parasite populations, e.g. in $V$. album ssp. austriacum populations from Babki $F_{I S}=0.424$ and from Rakoniewice $F_{I S}=-0.031$ (Table 5). In $V$. album ssp. austriacum populations, which have a greater percentage of diembrional fruits than $V$. album ssp. abietis, inbreeding is also greater: $F_{I S}=0.186$ and $F_{I S}=0.066$ respectively, and the differences between observed and expected heterozygosity are also greater: $H_{o}=0.216$ and $H_{e}=0.294$.

In the studied populations of Viscum album the mean reduction in heterozygosity resulting from inbreeding is $0.08 \%$ (Table 6). In V.a. ssp. album populations, the observed heterozygosity reaches the mean value of $H_{o}=0.199$, smaller than the expected from $\mathrm{H}-\mathrm{W}$ law $H_{e}=0.212$ (Table $5)$. These values are comparable to those in Scots pine, but two times greater than those for silver fir (Lagercrantz and Ryman 1990; Lewandowski and Burczyk 2002; Mejnartowicz 2004). However, in all populations the observed heterozygosity is lower, $H_{o}=0.252$, than that expected from H-W law, $H_{e}=0.292$, (Table 5). The above data, similarly to ratio $F_{I S}=0.113$ indicate excess homozygotes. As was mentioned above, one of the reasons for that can be kinship fertilization and polyembriony appearing among mistletoe shrubs. Relatively high heterozygosity observed in mistletoe populations can be related to a specific translocationheterozygosity-complex existing in male mistletoe plants. Viscum album is a diploid plant with $2 \mathrm{n}=20$ chromosomes. Female mistletoe plants are homogametic, but in male plants four chromosome pairs are complex-heterozygous. As a result of translocations, this chromosome forms hete-

TABLE 6. Summary of F-statistics and gene flow for all loci (Nei 1987a).

\begin{tabular}{ccccc} 
& Sample Size & $F_{I S}$ & $F_{I T}$ & $F_{S_{T}}$ \\
Average & 776 & 0.083 & 0.337 & 0.277 \\
\hline
\end{tabular}

$* N_{m}=$ Gene flow estimated from: Fst $=0.25(1-$ Fst $) /$ Fst. 
TABLE 7. Matrix of Nei's genetic distance between the studied 19 mistletoe populations. Viscum album ssp. album (1-9), V. album ssp. austriacum (10-13) and $V$. album ssp. abietis (14-19).

\begin{tabular}{|c|c|c|c|c|c|c|c|c|c|c|c|c|c|c|c|c|c|c|c|}
\hline Pop. ID ${ }^{*}$ & 1 & 2 & 3 & 4 & 5 & 6 & 7 & 8 & 9 & 10 & 11 & 12 & 13 & 14 & 15 & 16 & 17 & 18 & 19 \\
\hline 1 & 0 & & & & & & & & & & & & & & & & & & \\
\hline 2 & 0.007 & 0 & & & & & & & & & & & & & & & & & \\
\hline 3 & 0.009 & 0.007 & 0 & & & & & & & & & & & & & & & & \\
\hline 4 & 0.016 & 0.015 & 0.006 & 0 & & & & & & & & & & & & & & & \\
\hline 5 & 0.006 & 0.007 & 0.005 & 0.012 & 0 & & & & & & & & & & & & & & \\
\hline 6 & 0.021 & 0.011 & 0.015 & 0.028 & 0.015 & 0 & & & & & & & & & & & & & \\
\hline 7 & 0.015 & 0.014 & 0.010 & 0.026 & 0.006 & 0.019 & 0 & & & & & & & & & & & & \\
\hline 8 & 0.028 & 0.022 & 0.031 & 0.058 & 0.033 & 0.026 & 0.044 & 0 & & & & & & & & & & & \\
\hline 9 & 0.018 & 0.019 & 0.025 & 0.039 & 0.019 & 0.027 & 0.025 & 0.017 & 0 & & & & & & & & & & \\
\hline 10 & 0.198 & 0.199 & 0.171 & 0.188 & 0.191 & 0.197 & 0.164 & 0.191 & 0.236 & 0 & & & & & & & & & \\
\hline 11 & 0.207 & 0.195 & 0.202 & 0.229 & 0.193 & 0.175 & 0.193 & 0.150 & 0.162 & 0.231 & 0 & & & & & & & & \\
\hline 12 & 0.248 & 0.249 & 0.224 & 0.250 & 0.243 & 0.216 & 0.225 & 0.217 & 0.260 & 0.174 & 0.187 & 0 & & & & & & & \\
\hline 13 & 0.299 & 0.293 & 0.255 & 0.283 & 0.296 & 0.232 & 0.277 & 0.226 & 0.295 & 0.162 & 0.177 & 0.114 & 0 & & & & & & \\
\hline 14 & 0.171 & 0.179 & 0.186 & 0.247 & 0.165 & 0.177 & 0.159 & 0.116 & 0.126 & 0.412 & 0.233 & 0.241 & 0.357 & 0 & & & & & \\
\hline 15 & 0.175 & 0.178 & 0.191 & 0.252 & 0.174 & 0.181 & 0.172 & 0.120 & 0.114 & 0.435 & 0.226 & 0.294 & 0.359 & 0.021 & 0 & & & & \\
\hline 16 & 0.265 & 0.275 & 0.274 & 0.341 & 0.262 & 0.265 & 0.282 & 0.196 & 0.206 & 0.515 & 0.262 & 0.402 & 0.368 & 0.104 & 0.071 & 0 & & & \\
\hline 17 & 0.167 & 0.172 & 0.184 & 0.239 & 0.169 & 0.180 & 0.169 & 0.111 & 0.116 & 0.401 & 0.215 & 0.294 & 0.338 & 0.029 & 0.012 & 0.053 & 0 & & \\
\hline 18 & 0.164 & 0.159 & 0.176 & 0.230 & 0.155 & 0.175 & 0.147 & 0.112 & 0.109 & 0.405 & 0.223 & 0.284 & 0.359 & 0.015 & 0.013 & 0.092 & 0.021 & 0 & \\
\hline 19 & 0.175 & 0.191 & 0.186 & 0.241 & 0.165 & 0.177 & 0.161 & 0.134 & 0.137 & 0.388 & 0.218 & 0.343 & 0.314 & 0.058 & 0.052 & 0.090 & 0.056 & 0.046 & 0 \\
\hline
\end{tabular}

* Populations numbers are explained in Table 5.

rogametic zig-zag-octovalent (for cariological details see Mechelke 1976). The great number of rare alleles can also have some influence on the high level of heterozygosity in mistletoe populations from deciduous trees $\left(H_{o}=0.303\right)$, much higher than that observed in populations of $V . a$. ssp. abietis, $H_{o}=0.199$, and V.a. ssp. austriacum, $H_{o}=0.216$. In species dynamically increasing the area of occurrence, like Viscum album, heterozygotic individuals with rare alleles can have a selective advantage in the new environment.

\section{Percentage of polymorphic loci (\%PoL)}

$\%$ PoL is highest for V. album ssp. album (PoL $=80.9 \%)$, much higher than for V.a. ssp. austriacum $(P o L=65.48 \%)$, and V.a. ssp. abietis $(P o L=63.49 \%)$. The mean for all mistletoe subspecies is $P o L=72.18 \%$ (Table 5), and does not differ from that described for populations of Scots pine and fir trees, for which $P o L=71 \%$ (Lewandowski and Burczyk 2002; Mejnartowicz 2004).

\section{Gene flow among populations}

The presence of a large number of rare isoenzyme alleles only in some mistletoe populations seemed to indicate that gene flow inside the population was rather small and genetic diversity, resulting from many subpopulations, quite great (Table 4 and 6). Such conclusion can be confirmed by the gene flow $\left(N_{m}\right)$ estimated with Wright's indirect method $F_{S T}$, using differences between populations in allele frequency: $N_{m}=1 /\left(4 N_{m}+1\right)$, where $N=$ population size, $m=$ fraction of $N$ replaced with immigrants. Only 0.6 of the immigrant reaches Viscum album population in one generation's duration, $N_{m}=0.653$ (Table 6). According to Whitlock and McCauley (1999), estimating $N_{m}$ on the basis of $F_{S T}$ does not fulfill all theoretical assumptions of the model. Nonetheless the received data match perfectly the earlier results described in the literature review by Hamrick (1989), who maintains that gene flow in plants whose fruits, like mistletoe's, are eaten by animals is $N_{m}=0.621$ and in plants of mixed pollination $N_{m}=0.727$. Gene flow in the population of wind-pollinated Abies alba, a mistletoe host, is five times greater, $N_{m}=3.286$, despite the very heavy pollen of that species (Mejnartowicz 2004). The correlation of $N_{m}$ estimation with results of earlier studies on plants carrying seeds and fertilizing in a similar way to that of the mistletoe, confirms correctness of the applied investigation methods and the obtained data.

The $F_{S T}$ coefficient for 20 polymorphic loci ranged from 0.068 at $\mathrm{GDH}$ to 0.888 at $6 \mathrm{PGD}$ with the average $F_{S T}=$ 0.277 , which means that $28 \%$ of total genetic variation is due to interpopulation diversity and $72 \%$ is located within populations (Table 6).

In the dendrogram drawn according to Nei (1978) on the basis of interpopulation genetic distances (Table 7), three main groups were observed. The first one includes $V$. album ssp. album populations, the second one $-V$. album ssp. abietis, and the third - accumulated V. album ssp. austriacum populations. The biggest genetic distance in relation to other populations can be seen between $V$. album ssp. austriacum populations. The other populations form several smaller groups (Fig. 3). Results of studies on internal transcribed spacer (ITS) regions and cpDNA by Zuber and Widmer (2000), who analyzed Viscum album, also showed the distinction of three mistletoe subspecies described in this work by isozyme analysis. We suppose that the dendrogram structure received from our isoenzyme studies allows for a hypothesis that there are three species of mistletoe: V. album L., V. abietis Beck., and V. laxum Boiss, as was suggested by Szafer at al. (1924), Ehrendorfer (1967), and Bergmeier (1994).

\section{CONCLUSIONS}

There is a significant diversity within V.a. ssp. album and V.a. ssp. abietis. A still greater genetic distance separates V.a. ssp. austriacum populations. In V.a. ssp. album observed heterozygosity $H_{e}$ amounted to 0.303 , much higher than in populations V.a. ssp. abietis $\left(H_{o}=0.199\right)$ and 


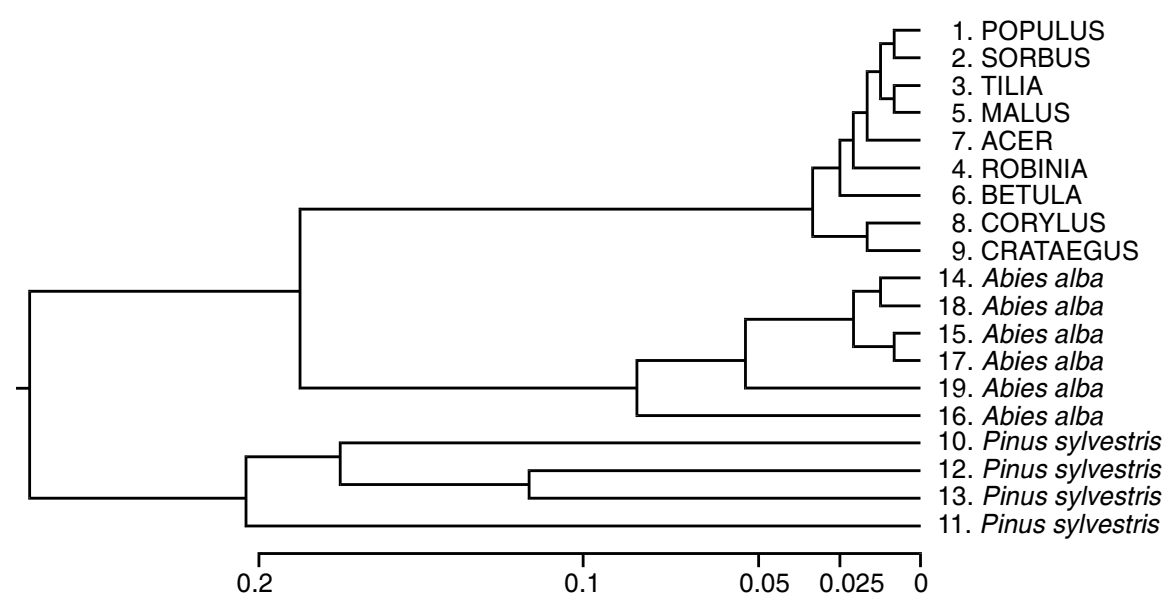

Fig. 3. UPGMA cluster analysis based on genetic distance on the data from Table 7. Method of Nei (1972) modified from NEIGHBOR procedure of PHYLIP Version 3.5. Viscum album ssp. album populations: 1-9, V.a. ssp. austriacum populations: 10-13, and V. A. ssp. abietis - populations: $14-19$
V.a. ssp. austriacum $\left(H_{o}=0.216\right)$. Similarly the actual $\left(N_{a}\right.$ $=2.48)$ and effective $\left(N_{e}=1.73\right)$ average number of alleles in $V . a$. ssp. album was higher than it was observed in V.a. ssp. austriacum $\left(N_{a}=2.06 ; N_{e}=1.60\right)$ and in V.a. ssp. abietis $\left(N_{a}=1.98 ; N_{e}=1.42\right)$ populations. From the 21 loci tested only one locus, SOD-A, was monomorphic.

A restricted gene flow between populations, great interpopulation differences $\left(F_{S T}=0.277\right)$, and great genetic distances between subspecies populations, shown on the dendrogram, suggest that mistletoe is composed of 3 species: $V$. album, V. abietis and V. laxum. There is a very small gene flow between Viscum album populations, with only one immigrant successfully entering a population per two generations $\left(N_{m}=0.653\right)$. Our observation is consistent with the results described earlier in plants, whose fruits are eaten by animals.

\section{ACKNOWLEDGEMENTS}

This work was financially supported by the project 6-PO4F 0319 of CSI Warsaw, and Institute of Dendrology PAS, Kórnik, Poland. The author is grateful to J. Kozłowska and M. Ratajczakowa for their excellent technical assistance.

\section{LITERATURE CITED}

BALL P.W. 1993. Viscum L. In: T.G. Tutin, N.A. Burges, A.O. Chater, J.R. Edmondson, V.H. Heywood, D.M. Moore, D.H. Valentine, S.M. Walters, D.A. Webb (eds), Flora Europaea. Cambridge Uni. Press. Vol. 1: 86.

BARNEY C.W., HAWKSWORTH F.G., GEILS B.W. 1998. Hosts of Viscum album: Eur. J. For. Path. 28 (3): 187-208.

BERGMANN F., MEJNARTOWICZ L. 2001. A reciprocal relationship between the genetic diversity at two metabolicallylinked isozme loci in several conifer species. Genetica 110: 63-71.

BERGMANN F., MEJNARTOWICZ L. 2002. Substrate specificity of glucokinase and fructokinase of several conifer species. Acta Soc. Bot. Pol. 71 (2): 125-127.

BERGMEIER E. 1994. Bestimmungshilfen zur Flora von Deutschland. Florist. Rundbr., Beih. 4: 420 pp.

BORATYŃSKI A., BORATYŃSKA K. 1976. Viscum album L. - Jemioła pospolita, Viscum laxum Boiss - Jemioła rozpierzchła. In: K. Browicz (ed.), Atlas rozmieszczenia drzew i krzewów w Polsce. PWN Warszawa-Poznań 19: 9-19. (in Polish)
BÖHLING N.,GREUTER W., RAUS T., SNOGERUP B., SNOGERUP S., ZUBER D. 2002. Notes on the Cretan mistletoe, Viscum album subsp. Creticum subsp. Nova (Loranthaceae/Viscaceae). Israel J. Plant Sci. 50: 77-84.

EHRENDORFER F. 1967. Liste der Gefäßpflanzen Mitteleuropas. Notring der Wissenschaftlichen Verbände Ostereichs, Wien, $253 \mathrm{pp}$.

FISCHER S., SCHEFFLER A., KABELITZ D., BUSSING A. 1996. Viscum album L. treatments in cancer. Proceedings of a working meeting held in Herdecke, Germany, 11. Oct., 1996. Anti-Cancer-Drugs 1997 (8) Suppl. 1: 33 -37.

GILES B.E., GOUDET J. 1997. Genetic differentiation in Silene dioica metapopulations: estimation of spatiotemporal effects in a successional species. Am. Nat. 149: 507-526.

HAMRICK J.L. 1989. Isozymes and the analysis of genetic structure in plant populations. In: D.E. Soltis, P.S. Soltis (eds), Isozyme in Plant Biology. Chapman \& Hall. London, 87-105.

HAMRICK J.L., LINHARD Y.B., MITTON J.B. 1979. Relationships between life history characters and electrophoretically detectable genetic variation in plants. Ann. Rev. Ecol. Syst. 10: $173-200$.

HATTON R.H.S. 1963-1964. Pollination of mistletoe (Viscum album L.). Proc. Linn. Soc. London 176: 67-76.

HEINRICHER E. 1920. Wie erfolgt die Bestäubung der Mistel; scheiden ihre Blüten wirklich Nektar ab? Biol. Zbl. 40: 514-527 .

KARKABOUNAS S., ASSIMAKOPOULOS D., MALAMAS M., SKALTSOUNIS A.L., LEONCE S., ZELOVITIS J., STEFANOU D., EVANGELOU A. 2000. Antiproliferative and anticarcinogenic effects of an aqueous preparation of Abies al$b a$ and Viscum album se abies, on a L-1210 malignant cell line and tumor-bearing Wistar rats. Anticancer Res. 20 (6B): 4391$-4395$.

KUIJT J. 1969. The mistletoes. In: The biology of parasitic flowering plants. Univ. of California Press, Berkeley, Los Angeles, 13-52.

LAGERCRANTZ U., RYMAN N. 1990. Genetic structure of Norway spruce (Picea abies): concordance of morphological and allozymic variation. Evolution 44: 38-35.

LEWANDOWSKI A., BURCZYK J. 2002. Allozyme variation of Picea abies in Poland. Scand. J. Forest Res. 17 (6): 487$-494$.

LINDACHER R. 1995. PHANART. Datenbank der Gefäßpflanzen Mitteleuropas. Erklärung der Kennzahlen, Aufbau und Inhalt. Veröff. Geobot. Inst. ETH Stiftung Rübel, Zürich. 436 pp.

MECHELKE F. 1976. Sex-correlated complex heterozygosity in Viscum album L. Naturwissenschaften 63: 390-391.

MEJNARTOWICZ L. 1979. Genetic variation in some isoenzyme loci in Scots pine (Pinus sylvestris L.) populations. Arboretum Kórnickie 24: 91-104. 
MEJNARTOWICZ L. 1996. Cisovka - the relic population of Abies alba and its relationship to man-made silver-fir stands in Białowieża Primeval Forest. Acta Soc. Bot. Pol. 65 (3-4): 319-328 .

MEJNARTOWICZ L. 2004. Genetic Analysis of Silver-fir populations in the North Carpathian and Sudeten Mountains. Acta Soc. Bot. Pol. 73 (4): 285-292.

MEJNARTOWICZ L., BERGMANN F. 2003. Mode of inheritance of aspartate aminotransferase in silver fir (Abies alba Mill.). Silvae Genetica 52 (1): 15-18.

MIREK Z., PIĘKOŚ-MIRKOWA H., ZAJĄC A., ZAJĄC M. 1995. Vascular plants of Poland a checklist. Polish Botanical Studies. Guidebook Series. W. Szafer Inst. of Botany. P.A.S. Kraków 15: 213-214.

NAGL W., STEIN B. 1989. DNA characterization in host specific Viscum album subspecies (Viscaceae). P1. Syst. Evol. 166: 243-248.

NEI M. 1972. Genetic distance between populations. Am. Natur. 106: 283-292.

NEI M. 1978. Estimation of average heterozygosity and genetic distance from a small numbers of individuals. Genetics 89: 583-590.

NEI M. 1987a. Molecular evolutionary genetics. Columbia University Press. 512 pp.

NOETZLI K.P., MÜLLER B., SIEBER T.N. 2003. Impact of population dynamics of white mistletoe (Viscum album ssp. abietis) on European silver fir (Abies alba). Ann. For. Sci. 60 (8): 773-779.

PIOTROWSKI A., OCHOCKA J.R., STEFANOWICZ J., ŁUCZKIEWICZ M. 2003. Molecular genetic survey of European mistletoe (Viscum album) subspecies with allele-specific and dCAPS type markers specific for chloroplast and nuclear DNA sequences. Planta Medica 69 (10): 939-944.

PRUS-GŁOWACKI W., URBANIAK L., ŻUBROWSKA-GIL M. 1993. Allozyme differentiation in some European populations of Scots pine (Pinus sylvestris L.). Genet. Pol. 34 (2): 159-176.

RIDGEWAY G.J., DHERBURNE S.W., LEWIS R.D. 1970. Polymorphisms in the esterases of Atlantic herring. Trans. Am. Fisheries Soc. 99: 147-151.

SCHRÖDER G. 1982. Einfluß eines Extraktes aus Viscum album L. auf Induktion, Wachstum, DNS- und Histongehalt von Crown-Gall-Tumoren. Dissertation, Fakultät II - Biologie, Universität Hohenheim.

SICILIANO M.J., SHAW C.R. 1976. Separation and visualization of enzymes on gels. In: Smith (ed.), Chromatographic and electrophoretic techniques. Heinemann Medical Books, London. Vol. 2: 185-209.

SMITH D. 1989. Iscador: Promising experience to date. AIDS Treatment news on-line. Immunet public database, 12/01/89, Issue No. 092.
STOPP F. 1961. Unsere Misteln. A. Zimsen Verlag. Wittenberg Lutherstadt. 76 pp.

STYPIŃSKI P.T. 1997. Biologia i ekologia jemioły pospolitej (Viscum album, Viscaceae) w Polsce. Fragmenta Floristica et Geobotanica, Series Polonica, Suppl. 1: 3 -115.

SZAFER W., KULCZYŃSKI S., PAWŁOWSKI B. 1924. Rośliny polskie. Opisy i klucze do oznaczania wszystkich gatunków roślin naczyniowych rosnących w Polsce bądź dziko, bądź też zdziczałych lub częściej hodowanych. Wyd. I. Książnica Atlas, Lwów-Warszawa, 736 pp. (in Polish)

SZAFER W., KULCZYŃSKI S., PAWŁOWSKI B. 1953. Rośliny polskie. Opisy i klucze do oznaczania wszystkich gatunków roślin naczyniowych rosnących w Polsce bądź dziko, bądź też zdziczałych lub częściej hodowanych. PWN Warszawa, 1020 pp. (in Polish)

TSOPELAS P., ANGELOPOULOS A., ECONOMOU A., SOULIOTI N. 2004. Mistletoe (Viscum album) in the fir forest of Mount Parnis, Greece. Forest Ecol. Manag. 202 (1-3): 59-65.

VALLAURI D. 1998. Dynamique parasitaire de Viscum album L. sur pin noir dans le bassin du Saignon (prealpes francaises du sud). Ann. Sci. For. 55: 823-835.

WANGERIN K. 1937. Loranthaceae. In: W. Wangerin, C. Schröter (eds), Lebensgeschichte der Blütenpflanzen Mitteleuropas. Verlag Eugen Ulmer, Stuttgart: II (1): 954-1231.

WENDEL J.F., WEEDEN N.F. 1989. Visualization and interpretation of plant isozymes. In: D.E. Soltis, P.S. Soltis (eds), Isozymes in Plant Biology. Chapman \& Hall. London, 5-45.

WEEDEN N.F., WENDEL J.F. 1989a. Genetics of plant isozymes. In: D.E. Soltis, P.S. Soltis (eds), Isozymes in Plant Biology. Chapman \& Hall. London, 46-72.

WHITLOCK M.C. 2003. Fixation probability and time in subdivided populations. Genetics 164 (2): 767-779.

WHITLOCK M.C., McCAULEY D.E. 1999. Indirect measures of gene flow and migration: F-ST not equal $1 /(4 \mathrm{Nm}+1)$. Heredity $82: 117-125$.

WRIGHT S. 1965. The interpretation of population structure by F-statistics with special regard to system of mating. Evolution 19: 395-420.

YEH F.C., YANG R. 1999. Popgene version 1.31. Freeware for population genetic analysis.

ZENKTELER E. 1996. Jemioła - wybrane aspekty szkodliwości. Hodowla Roślin i Nasiennictwo. Biuletyn Branżowy (1): 36-43. (in Polish)

ZIELIŃSKI J. 1997. Jemioła pospolita Viscum album L. na terenie lewobrzeżnego Szczecina: Zeszyty Naukowe A.R. w Szczecinie. Rolnictwo 66: 69-87. (in Polish)

ZUBER D. 2004. Biological flora of central Europe: Viscum album L. Flora 199 (3): 181-203.

ZUBER D., WIDMER A. 2000. Genetic evidence for host specificity in the hemi-parasitic Viscum album L. (Viscaceae). Mol. Ecol. 9 (8): 1069-1073. 